\title{
Interest Rate Targeting: A Monetary Tool for Economic Growth in Nigeria? - Stakeholders' Approach
}

\author{
Obadeyi James ${ }^{1, *}$, Akingunola Richard ${ }^{2}$, Afolabi Victor ${ }^{3}$ \\ ${ }^{1}$ Department of Accounting and Finance, Faculty of Humanities and Management Sciences, Elizade University, P.M.B 002, Ilara- \\ Mokin, Ondo State, Nigeria \\ ${ }^{2}$ Department of Accounting and Finance, Olabisi Onabanjo University, Ago-iwoye, Ogun State, Nigeria \\ ${ }^{3}$ Department of Banking Supervision, Central Bank of Nigeria (CBN), Lagos, Nigeria \\ *Corresponding Author: georgejames2006@yahoo.com
}

Copyright (C) 2013 Horizon Research Publishing All rights reserved.

\begin{abstract}
The paper assessed interest rate impact on economic growth in Nigeria, considering the stakeholders' approach. The continuous increase in interest rate always results to a slow economic growth. It is believed that interest rate may not eventually lead to lull economy especially in industrialized economies because these economies do not totally rely on assembling and consumption of goods and services, but majorly on production and distribution of goods and services[1]. The study adopts simple ordinary least square method to identify existing relationship between variables. The regression results were significant and Error Correction Mechanism helped to correct the dynamism that might exist. The time series analysis was adopted for 40 years (1970-2010), which shows evidence and supports that larger proportion of borrowing by Nigerian government, which are majorly financed by the apex bank has led to uncontrollable excess liquidity and inability of locally manufacturing firms, and small enterprises to raise loanable funds from banks. The paper therefore concluded that it will be difficult to generalize interest rate as equal either in developed or developing economies as result of the significant and un-comparable difference in social -economic belief, approaches and existing structures. It suggests that interest rate should play an un-comparable role in enhancing economic growth and sustainable activities in Nigeria.
\end{abstract}

Keywords Interest Rate, Inflation, economic growth, Central Bank of Nigeria (CBN), Nigerian Deposit Insurance Corporation (NDIC), Nigeria

\section{Introduction}

Interest rate may be regarded as a return on investment or cost of capital. It plays a major roles in the pursuit of macro-economic stabilization in Nigeria. The obvious adverse relationship that exists between interest rate and economic growth in Nigeria causes for economic concern and deliberations. Truly, the financial sector (banks) is the engine of growth in any economy given its function of financial intermediation roles. Financial institutions (Banks) facilitate capital formation, and promote economic growth, but interest rate (MPR) at 12\% - the rate at which banks lend to their customers may be regarded as high [2,3].However, banks' ability to engender economic growth and development depends on the health and stability of the financial system[4]. The globalization of banking sector, which is parallel to globalization of the financial system and the growth in multinational corporations in general cannot manage the most unpredictable and controllable monetary policy instruments[5]. The need for a strong reliable and viable financial sector is underscored by the fact that the industry is one of the few sectors in which the shareholders' fund is only a small proportion of the liabilities of the enterprise. In all ramifications, this makes the banking sub sector the most regulated sector in any economy [6]. The structural adjustment programs (SAP) that was inaugurated in Nigeria in 1986 (i.e. almost three decades ago), have not successfully saved the country from macroeconomic distortions. While such distress becomes obvious, the internal and external debts have just increased from US $\$ 6 \mathrm{bn}$ and US $\$ 4 \mathrm{bn}$ to over US\$36bn and US\$6bn respectively in 2013[2]. The ability of the Monetary Policy Committee (MPC) to retain the interest rate remains insensitive, high interest rate discourages both local and global investors to invest in the real sector (manufacturing, agriculture etc.); lack of promoting industrialization by Nigerian government. CBN's ability to actively control inflation in the short-run may be difficult but in long-run is possible in a guided economy- which is common in developed economies[7].The ability of Central Bank of Nigeria (CBN) to effectively manage and control monetary policy instruments particularly interest rate will prevent increase in money supply from becoming a major source of disturbance to Nigerian economy[8]. Distortions have forced many financial and non-financial institutions to relocate to other economies 
(off-shore) where the environment is even weaker and uncertain [9]. The reform of financial markets and banks has been a consistent force in the development of the financial system in developing countries [10]. The interest rate of double-digit will simply lead to deepening of unemployment crisis, difficulty in re-energizing the slow and non-vibrant real economy. However, it will be difficult to generalize interest rate as equal in industrialized economies and less developed economies (LDEs) as result of the significant and un-comparable difference in social - cultural, economic and political belief, and existing structures. The adoption of non-tight interest rate regime will lead to increase in Gross Domestic Product (GDP), reduction in inflation rate, less unemployment rate, improvement in the balance of payment, rise in the accumulation of financial savings, exchange rate stability, less excess liquidity and increase in external reserves[11,12]. Consequently, Less Developed Countries have taken steps to liberalize their interest rates as part of the reform of the entire financial system (banks) in Nigeria as witnessed in 2005- during Prof. Charles Soludo as the CBN governor and recently in 2011- the incumbent governor, $\mathrm{Mr}$. Lamido Sanusi. The reform in the financial market and banks remain a consistent force for the development of less developed economies[10]. In eighties, Nigerian economy witnessed rigid exchange rate, high interest rate and bank assets controls resulting in low direct investment[13]. Monetary and credit aggregates movement are sluggish, which permits continuous pressure on the financial sector, which in turn necessitated a reform of the financial system[14].

The paper is further divided into four sections. Section two emphasizes on empirical literature review. Section three addresses issues on research methodology, however, section four explains the empirical results and section five makes the concluding phase.

\section{Literature Review}

The increase in interest rate trend provides a rapid growth via un-comprised resource allocations and increased in productivity level[15]. The recent increase in interest rate in Nigeria was a result of core inflation, declining trend in gross domestic growth, conflicting price signals and global uncertainties [2]. It must be noted that there are different types of relationships that often exist between developed and less developed countries in terms of economic growth, interest rate, inflation rate, exchange rate and possibly money supply in the economy[16]. The sluggish monetary policy rate of $12 \%$, has shown a very wrong signals of supporting a tight interest rate regime, excess liquidity - cash held by banks above regulatory requirement for the exact bank and rising national debt. The largest sources of investment capital consists of financial institutions, but is never households and the three- tier of governments (Federal, State and Local) funds[17].

There is consensus that financial development has had a significant positive impact on the growth rates of countries. The extent to which these results can be interpreted has been influenced by financial liberalizations, which has remained undefined and ambiguous. The growth of financial development occurs simultaneously with significant structural, socio- cultural, political and economic transformations[18]. The increase in interest rate is as a result in the response to the uptick in food inflation, and its reduction will lead to reduction in core inflation, Gross Domestic Growth. The decision was as a result of structural nature of inflationary pressures. Report has shown that the initial level of financial development is positively associated with a country's GDP growth rate. Historical evidence shows that the classical school was the first school of thought to advocate deregulation which heralded the beginning of the laissez-faire approach in economics. Adam Smith in his wealth of nations and theory of moral sentiments stated that human conduct was naturally activated by four motives: selflove, sympathy, desire for freedom, and prosperity to exchange one thing for another. To Smith the guiding and beneficial force that ensure the good of society was self-interest, observed that as each individual purses his own advantage he would be led by an "invisible hand" to promote an end, which was not part of his original attraction. This invisible hand refer to the dynamics of the price system that is without any conscious guide, but meet with the wishes and aspirations of any economy either developed or less developed[19]. It must be noted that the price system will adequately guarantee efficiency because economic forces will respond instantaneous to price signals, to direct resources to activities where profit abound and avoid losses. In this case, the price system, with automatic signal is self-efficient, regulatory equilibrium will be a temporary abbreviation and market will be set in motion to ensure that equilibrium is re-established [20].Therefore an effective price system is the "messiah" in Nigerian Financial Market (Nigeria Stock Exchange) to thrive again, since its comatose operation as a result of the negative effect of global economic and financial crises, which occurred for almost half- decade ago. Economic regulations completely allow any means of directives and control which government impose on the administration and pricing system in the economy in order to achieve a macro economic objectives and aspirations. Scarcity of resources is an economic reality[21].A society must have to operate with the price system so as to help ration out the limited resources among competitive uses and hence provide efficient system for distribution of income among factors of production. The price system operates in an impersonal manner and therefore eliminates corruption that has grossly and negatively affects the growth of Nigerian -planned economy[22]. When the regulator adopts an anti-inflationary monetary policy support, the apex bank reduce the money supply in order to control inflation, among other effect, the interest rate on market securities rise on the floor of Nigerian Stock Exchange, thereby making transaction cost on the market floor unbearable[23]. In anticipation of higher yields and profits, 
bank will raise the interest rate on their savings deposit of customers to attract more funds higher than investing in yielding securities. People that are already holding securities funds may be discouraged if prices of securities have fallen because of the rise in interest rate on present securities, many investors preferred to invest in Treasury bill (TB) in the money market[24]. However, the highly accepted justification for a high interest rate policy in less developed countries (Nigeria inclusive) is achieved via the presence of liquidity constraints on private investment decision. It has been argued that no nation has ever developed without an appreciable growth in financial sector[25,53]. As at 2012, the inflation rate remains at $12.4 \%[2]$. It shows that the continuous increase in interest rate will automatically promote excess liquidity, increase in money supply in circulation, inflation, inevitable burden of rising subsidy payments and the demand for more United States dollar during bi-lateral trade between Nigeria and other countries. The apex bank monetary policies have not helped to achieve macro-economic policies of the nation to achieve its goals of high economic growth, increase in balance of payment equilibrium, stable and active exchange rate, low inflation and interest rate, etc.[26].The Monetary Policy Rate has remained unchanged for nine consecutive times and there is no evidence that it will be reduced from double digit to single digit; trading in equities on the second- half of this year, 2013 has been negative on the floor of Nigerian Stock Exchange (NSE), - the share index lost $0.92 \%$ to close at $36,164.31$ points, the net foreign inflows into the Nigerian equities equal \#29.3billion naira, compared with \# 93.8 billion naira in 2012.It therefore shows that the economy is under a rigid monetary framework, financial and economic distortions.

\subsection{Capital Formation}

Capital formation remains the process of building-up nation's capital stock via investment in the plants, tools and equipment productions; and which also involves the increasing of capital as a result of efficient utilization of human and physical resources. However, capital and labor are one of the important factors which successfully governs the quantity of nations' output composition. In Less Developed Economies (LDEs), income is very low, but labors are at a surplus magnitude. It must be noted that investment requires steady growth, which could be examined by technical capacities of capital goods. In developing and advanced economies, if resources were not well utilized, it may be difficult for investment to fully offsets desired saving, which may result to a mismatch between capacity of the capital-goods industries in equipment and trained labor as well as inefficiency of financial markets. The mismatch may further limit economic growth in these economies as a result of secular changes and international differences. The low income earners have led to the production, distribution of goods and services; and investment occupy a deficient trend. The availability of machines and equipment will definitely promote and expand production scale, resulting to increase in output and income, reducing high unemployment and crime rate; as well as the problem of balance of payment disequilibrium will be solved [44,61]. However, the equilibrium of physical and human capital may be essential to control inflation trends in the economy. Capital formation plays a crucial roles in the country's economic growth. Despite high interest rate in eighties, the industrialized economies thrived; it is as a result sizeable proportion of capital formation to Gross Domestic Product (GDP) growth, contrary, to Less Developed Economies -Nigeria inclusive [27]. During the Structural Adjustment Programme (SAP) in 1986, Nigerian government ensure to improve capital formation and pursue economic and financial growth; to permit private sector participation in promoting economic growth. It eventually resulted to positive interest rate; and ensuring loanable funds available for the development of the real sector. Since the economic reform, capital formation has continued to fluctuate and which later resulted to unstable foreign exchange rate, high interest rate, high unemployment and corruption in government ministries, departments and agencies (MDAs); lack of adequate infrastructural facilities and social amenities- poor energy supply, absence of good road networks, collapse of health-care and educational sector etc., which all have negative effect on capital formation [28].

\subsection{Interest Rate and Economic Growth}

Interest rate is a rate of return on investment, when low interest rate is charged on loan to encourage investors and high on savings; and it becomes cost of capital, when low interest is charged on savings and cost of borrowing by investors is high. The low interest rate regime attracts lower cost of borrowing by investors, with increase in investment and the purchase of consumer durables. A low interest rate strengthens the banks to relax the lending policy in order to promote and guild firms and household spending cultures. When the interest rate is low, it helps to create a platform for securities to be highly attractive to purchase; and ability to raise firms' and households' financial assets vice versa. A low interest rate can force local currency to be devalued, as a result of demand for domestic goods rises, most especially when imported goods become costly. These factors among others would necessitate economic growth, consumer spending pattern and investment. However, economic growth is a proportion of a nation's potential output. Economic growth has re-examined the reality behind the disparity in growth rate of countries overtime; and this act has influenced government decisions on spending pattern and tax rate regime in order to realize easy growth rate[29]. There is a negative relationship that exists between interest rate and economic growth, considering the structural nature of inflationary trend, pressure and complete pro-cyclical nature of Nigerian economy. The average real GDP rate was less than $6 \%$ in $1970 \mathrm{~s}$, and later became worse, until the economic reform of August, 1986. Since then, positive GDP 
has been sustained till date, but at a very low rate.

\subsection{Nigerian Contemporary Challenges}

The basic problem facing most developing countries include capital-shortage, inadequate supply of high-level manpower and ineffective management of existing resources, in that context, capital is often claimed to be in short supply, while labor is surplus and cheap[32].The importance of money capital is based on the need for money to acquire real capital in form of machinery, equipment and other assets with which productive activities could be undertaken. The importance of capital is therefore seen in terms of the size of investment and savings mobilization required to achieve meaningful development[33].Overall, the low interest's rates regime resulted in inefficient production and excessive demand for credit. The change of interest rates policy is a problem as a result of investment contraction in Nigeria that may not have any connection with the increase in lending rates that accompanied interest rates reform and low interest rates policy; the regulation of interest rates could discourage savings mobilization due to contradictions [34].While, it is impossible to achieve economic growth without adequate investment, savings generates investment. The financial feature preceding the emergence of financial reforms in 1986 was that, the sector was highly repressed. Variables such as interest rate controls, selective credit guidelines, ceiling on credit expansion and use of reserve requirements and other direct monetary control instruments were common features of financial system. In addition, entry into banking business was restricted and public sector-owned banks dominated the industry[35,36].Therefore, fundamental financial reform implemented in Nigeria included liberalization of financial markets and institutional reforms to the prudential regulatory framework of government banks. Reforms in the financial sector started with the liberalization of interest rates in 1986. This took place in a phased manner lasting several years, which began with administered interest rates being raised before partial and then full control was implemented[35].Treasury Bill (TB) auctions were also introduced to allow a role for market forces to influence TB rates, to facilitate the use of indirect techniques of monetary control and sectorial credit directives were also liberalized[37].There is no doubt that the CBN within its mandate had attempted to influence interest rate changes through its intervention at the discount window especially through the Monetary Policy Rate (MPR) and its liquidity management strategy. The period before the introduction of SAP witnessed the use of direct administrative controls in the management of interest rates. The early years of the reform witnessed a lot of policy inconsistencies, policy reversals, macroeconomic distortions and the absence of the political will to implement some of the desirable options in the reforms. Generally, since the introduction of SAP in 1986, interest rate management has been a mixture of deregulation and guided deregulation [38,39]. Central Bank of Nigeria $(\mathrm{CBN})$ has taken a pre-emptive measure to secure fortune, build confidence in depositors and avert failures [40].

\subsection{The Determinants of Interest Rates}

In United States, policymakers keep benchmark of interest rate near $0 \%$ till 2015, while in Nigeria, $12 \%$ has continuously been retained, and Consumer Price Index (CPI) is at $8.1 \%$, year - on- year and which later rose to $9.5 \%$ in February 2013 [30]. It may be difficult to have interest rate reduced to less than $10 \%$, considering lack of unstable and rigid exchange rate system, excess liquidity, and excess demand for American dollar. However, monetary policies in less developed economies (LDEs) often adopt terms and conditions in developed economies, which serves as a guide particularly with a time lag. The short- term interest rates adopted in less industrialized countries (Nigeria inclusive) were always quite high [31]. With regard to the influence of fiscal policy, especially budget deficit, on the rate of interest. Therefore, interest rates are uncontrolled, a fiscal deficit financed through domestic borrowing would result in high real interest rates. Interest rates are determined by some factors which include: investment, level of savings (consumption), demand for money, money supply, price expectations capital accumulation, technical knowledge, duration of loan uncertainty, price of an income-reducing asset, difference in the cost of administering credits, changes in the demand to borrow money, changes in government's deficit, influence of monetary authorities as well as bank administration of interest rates through credit rationing etc.[42]. Alternatively, under fiscal deficit the rate of interest could be controlled in such a way that the implicit tax on financial assets becomes a hidden source of revenue for government to finance the deficit. External sector developments are also known to affect domestic interest rates. Such factors include external trade, world interest rate and prices as well as exchange rates. The impact of world exchange and interest rates depend on the degree of financial openness of the domestic economy [41,45].

\subsection{Interest rate and Savings}

Incentives are needed for consumers to postpone current consumption. Collecting interest on savings means that more can be consumed in the future, but unless the interest rate is high enough people will choose to save very little[14]. The feeble CPI in measuring inflation has resulted to national economic woes as Nigerian economy continues to experience endless banking fragility, fiscal and monetary tightening[3].The interest rate induce savings, which depends on the household, but it must be high enough to cover time preference and risk. Time preference refers to how people rank current versus future consumption. If they value future consumption highly relative to current consumption then savings will take place at relatively low interest rate. Though, there is need to know the important distinction between real and nominal interest rate. The 
former is simply a nominee rate adjusted to consider inflation or better still take account of inflation on the real value of the loan while the latter is normally observed and quoted and represents the actually money paid by the borrower to the lender, expressed as a percentage of the sum borrowed over a period of time [42].Therefore, risk affects savings decision because the future is unknown. If you are afraid that your savings will not be there when you want to withdraw them, you will need a very high interest rate to overcome the risk of loss. On the other hand, if you are confident that your savings will be there in future you may be willing to save at a low interest rate. Moreover, income is a determinant of savings, the higher your income the higher your possibility to save and invest vice versa as long as no inflationary problem in the economy, which can bring about changes in prices of goods and services. The changes can affect the consumption pattern, investment and the ability to save as an individual. Hence, for financial sector to actively play intermediation role, real interest rate must be positive. In a situation, where central bank adopts an anti-inflationary monetary policy, the money supply reduced in order to control inflation, among other effect, the interest rate on market securities rise. In anticipation of higher yields and profits will raise the interest rate on their savings deposit to attract more funds more to invest than in higher yielding securities. People that are already holding securities funds that their prices have fallen because of the rise in interest rate on present securities, may be forced to sell them and deposit their fund with intermittences, where higher interest rates on savings deposit is earned [41,46]. Non-Bank Financial Institutions (NBFls) may raise the interest rate on their savings accounts of depositors, as a result of this act, the public reduces the market rate of interest. Though, the most favored justification for a high interest rate policy in less developed countries is derived from the presence of liquidity constraints on private investment decision. No singe economy has ever developed without an appreciable growth in financial and real sectors. Growth of the banking sector, competitiveness and efficiency of the system, the quality of banks' loan portfolios and the system integration's with the international banking system would need to be evaluated.

\subsection{Interest Deregulation and Inflation Rate}

Interest rate is the rental payment for credit usage by borrowers, investors and returns for parting with lenders' liquidity. Also, Interest rate may be regarded as the price of the credit that is ambiguous due to inflationary pressure. However, deregulation is the act of eliminating government influence and regulatory capabilities in order to sustain and achieve a more efficient and stable market. Deregulation often helps to forge a healthy competition in any sector. The price system will guarantee efficiency because economic forces will respond instantaneous to price signals, and avoid losses, thus ensuring efficient allocation of available human and non-human resources. The society economic problems are made simple as market signal through the interplay of forces of demand and supply will always serve as a solution. In this case, the price system, with automatic signal is self-efficient, regulatory equilibrium will be a temporary abbreviation and market will be set in motion to ensure that equilibrium is re-established. Economic regulation in all circumstances allow every form of directives and control which government impose on the administration and pricing system in the economy in order to achieve a macro economic objectives [39].The price system operates in an impersonal manner and therefore eliminates corruption and nepotism that are always common in planned economies (Nigeria exclusive).

The Nigerian economy seemed to have experienced moderate inflation before the economic reform in August 1986. Since this reform era, the economy has witnessed the unfavorable consequences of inflation in the country in an assumed intolerable dimensions. There exists a positive relationship between inflation and growth in the short run, but economies (either developed or under-developed) with continuous increase in inflation rate may be forced to face some macro-economic challenges - low purchasing power of the local currency, poor price system and fluctuation of exchange rate etc. [43]. Within three months, inflation dropped to $8.6 \%$ in March from $9.5 \%$ as recorded in February 2013 , as at now is $9.1 \%$.It shows that the monetary tightening policy of $\mathrm{CBN}$ has not kept unemployment to full employment, reduce poverty among Nigerians and even increase the value of the domestic currency (naira). The instability in the financial market and banks, have shown that the Central Bank's inability to actively manage the monetary policies have negative effect on the economy, thereby leading to increase in demand for dollars and with undesirable effect on resource allocation. High inflation has been found to have undesirable consequences on economic parameters. Inflation was $12.24 \%$ in 2012 and $9.1 \%$ as at June, 2013 in Nigeria. Nigeria has experienced high inflation, thereby targeting the real interest rate on a negative trend most of the time. This act has made interest rate to be difficult to control, and the real interest rate remaining negative, savings and investment have remained low, and the economy has experienced weak industrial infrastructure. The high rate of inflation in the economy has tendency to reduce demand for bank's financial assets and hence, impair the process of financial intermediation in the banking sector as deposits would move from the banking system into real estate and inventory speculations among others [56,61].

\section{Methodology}

To determine interest rate as monetary tool for economic growth in Nigeria, requires to establish the relationship between the variables for this study, Ordinary Level Square (OLS) is adopted, with simple econometric models in order to arrive at logical conclusion. The augment is to investigate the functional relationship between gross capital formation, 
gross domestic product, inflation rate, investment and interest rate. However, model specifications are presented as follows:

$$
\mathrm{Y}=\beta_{0}+\beta_{1} \mathrm{X}+\mu
$$

$\mathrm{Y}$ is a function of independent variable which is $\mathrm{X}$ and $\mu$ is stochastic variable/ an error term. The above model adopts these models for the study as stated below:

\section{MODEL I.}

$$
\text { In Gef }=\beta_{0}+\beta_{1} \mathrm{I}_{\mathrm{n}} \mathrm{INT}+\mathrm{U}_{2}
$$

Equation 2 above shall test the impact of interest rate on capital formation in Nigeria.

Where

Gcf $=$ Gross Capital Formation

INT $=$ Interest Rate

$\beta_{0}$ and $\beta_{1}$ - are estimate parameter or intercept

$\mathrm{U}_{2}$ - Stochastic variable/Error term

\section{MODEL II}

$$
\text { In Gcf }=\beta_{0}+\beta_{2} I_{n} \text { GDP }+U_{3}
$$

Equation 3 above shall test the impact of Gross domestic product on capital formation in Nigeria.

Where,

GDP $=$ Gross Domestic Product

$\beta_{0}$ and $\beta_{2}$-are estimate parameter

$\mathrm{U}_{3}$ - Stochastic variable/Error term

\section{MODEL III}

$$
\text { In Gcf }=\beta_{0}+\beta_{3} \text { In INF }+\mathrm{U}_{4}
$$

Equation 4 above shall test the impact of inflation rate on capital formation in Nigeria.

Where

$\mathrm{INF}=$ Inflation Rate

$\beta_{0}$ and $\beta_{3}$-are estimate parameter

$\mathrm{U}_{3} \quad$ - Stochastic variable/Error term

\section{MODEL IV}

$$
\mathrm{Ln} \mathrm{Gcf}=\beta_{0}+\beta_{1} \text { In INT }+\beta_{2} \text { In GDP }+\beta_{3} \text { In INF }+\mathrm{U}_{5}
$$

Equation 5 above shall test the impact of interest rate, gross domestic product, and inflation on capital formation in Nigeria.

Where

$\beta_{0,}, \beta_{1}, \beta_{2}$, and $\beta_{3}-\quad$ are estimate parameter

All the variable remained as defined above, $U_{5}$ is Statistic variable

The ratio of explained variation to the total variation which is called the coefficient of determination can be represented by $R^{2}$. It is used to show the percentage of total variation i.e. independent variables that are explained by the independent variable. The ratio lies between 0 and 1 and the nearer to 1 , the greater is the explanatory ability of the estimates.
However, in order to determine the goodness of fit of the regression line and reliability of the result the quantitative tools such as the adjusted co-efficient of determination (adjusted $\mathrm{R}^{2}$ ), T - statistic, f-statistics and the Durbin Watson Statistic will be employed.

The Granger causality test is used to determine the direction of causality between Gross Capital formation and Gross Domestic Product (GDP) in Nigeria However, it is very crucial that since the lack of understanding of the exact causality may result to wrong specification and consequently giving an erroneous inferences concerning the two variables. The model for John Weiner Granger causality test (as described by Granger, 1969) is hereby explained below: Let Gross Capital formation (GCF) and Gross Domestic Product (GDP) as well as Interest Rate (INT) and inflation (INF) being two time series with zero means. Recall, granger causality modeling is very sensitive to the lag length. The simple causal model is:

$$
\begin{gathered}
\operatorname{Gcf}_{t}=\sum \alpha i: \operatorname{Gcf}_{t-i}+\sum \beta j ; I N T_{t-j}+U_{1 t} \\
I N T T_{t}=\sum \lambda j: \operatorname{Gcf}_{t-j}+\sum \delta j I N T_{t-j}+U_{2 t} \\
t=1
\end{gathered}
$$

Where Gcf = Gross Capital Formation INT $=$ Interest Rate

$\mathrm{U}_{1 \mathrm{t}}$ and $\mathrm{U}_{2 \mathrm{t}} \quad=$ disturbance variables / uncorrelated variables

$\alpha i$ and $\lambda \mathrm{j}$ are estimated coefficient on lagged Gcf in equation (6) and (7) respectively.

$\beta_{\mathrm{j}}$ and $\delta \mathrm{j}$ are estimated coefficient on lagged INT in equation

(6) and (7) respectively.

$\mathrm{t}-\mathrm{i}$ and $\mathrm{t}-\mathrm{j}=$ Lag values

$\mathrm{n}=$ : lag length (It can be infinity but in practice, due to the finite length of available data, ' $n$ ' is thereby assumed finite and shorter as a given time series.

However, the Granger Causality Test above explains that interest rate (INT) is causing Gross Formation (Gcf) provided $\alpha \mathrm{i}$ is not zero (o). Also, in some vein; Gross Capital formation (Gcf) is causing Interest Rate (INT) if $\delta \mathrm{j}$ is not zero (o) i.e. mathematically, $\alpha i=\delta j \# 0$. Therefore, if both of these events exist, then serial to be a bilateral relationship between Gross Capital formation (Gcf) and Interest Rate (INT).The use of simple/multiple regression model and the estimation of their respective parameter on the basis of OLS form and estimated parameters are subjected to various statistical and reliability tests in a bid to know whether the estimates are theoretically meaningful and satisfactory statically. For these reason, three (3) criteria will be of great help. These include Economic theory criterion, statistical criterion and the econometric criterion. The Economic criterion is determined by economic theory postulates, the coefficients of economic model are the constant of the economics theory, signs and sizes of the estimates of the 
parameters are defined. If in the course, the estimates of the parameters suddenly turn up with signs and sizes not conforming to the theoretical expectations, it would be rejected unless there is a good and tenable reason to justify such misdemeanor of signs. Also, the statistical criterion is focused at the statistical evaluation of the estimates reliability. The standard errors of the estimated parameters will first measure the dispersion of estimates from their real parameters. The larger the standard errors, the less reliable such as estimate become and vice-versa. The t-statistics will be employed to test any hypothesis concerning the time value of the population its applicability is based on the goodness of fit of the equation. The value of $\mathrm{R}^{2}$ range between zero and one. Hence, the nearer to one the greater the explanatory power of the variation. This, it shows the proportion of the variation among the economic variables as regard the study. The appropriate comparison of the calculated values of $t$ and $f$ statistics with the theoretically values will give the final verdict and the overall test of Durbin Watson statistic will test for the presence of auto-correlation between and among the variables. The value of Durbin Watson ranges between 0 and 2. The nearer of two, the higher the level of auto-correlation and vice-versa. Hence, equation (8) \& (9) are shown below:

$$
\begin{gathered}
\mathrm{INF}_{\mathrm{t}}=\sum_{\mathrm{t}=1} \alpha \mathrm{i}: \mathrm{INT}_{\mathrm{t}-\mathrm{i}}+\sum \beta \mathrm{jNF}_{\mathrm{t}-\mathrm{j}}+\mathrm{U}_{1 \mathrm{t}} \\
\mathrm{GDP}_{\mathrm{t}}=\sum_{\mathrm{t}=1}^{\mathrm{n}} \lambda_{\mathrm{t}=1} \mathrm{GCF}_{\mathrm{t}-\mathrm{j}}+\sum_{\mathrm{j}=1}^{\mathrm{n}} \mathrm{GDP}_{\mathrm{t}-\mathrm{j}}+\mathrm{U}_{2 \mathrm{t}}
\end{gathered}
$$

Where Gcf = Gross Capital Formation

$\mathrm{GDP}=$ Gross Domestic Product

$\mathrm{INF}=$ Inflation Rate

INT $=$ Interest Rate

$\mathrm{t}-\mathrm{i}$ and $\mathrm{t}-\mathrm{j}=$ Lag values

$\mathrm{U}_{1 \mathrm{t}}$ and $\mathrm{U}_{2 \mathrm{t}}=$ disturbance variables/uncorrelated variables/white noise error term

Both $\alpha \mathrm{i}$ and $\beta \mathrm{j}$ are estimated coefficient on lagged Interest rate (INT) and Gross Inflation (INF) in equation (8).

Also, $\lambda \mathrm{i}$ and $\delta \mathrm{j}$ are estimated coefficient on lagged Gross Capital Formation (GCF) and GDP in equation (9).

$\mathrm{n}=$ lag length (It can be infinity but in practice, due to the finite length of available data, ' $n$ ' is thereby assumed finite and shorter as a given time series.

Theoretically, most of the economic variables that are shown in time series econometric models are non-stationary[47]. Therefore, it is very essential and of great importance to carry out the Unit Root Test for stationarity. Phillips-Perron. It must be noted that in order to avoid the spurious regression problem that may arise from regressing a non-stationary time series on one or more non-stationarity time series, there is need to transform non-stationary time series to make them stationary which can be in form of difference stationary or trend stationary
$[48,49]$.To determine if the time series data is stationary or non- stationary, for the purpose of this research work, the widely used Augmented Dickey - Fuller (ADF) test (Dickey and Fuller 1979) also (Phillips and Perron1983), tests are employed. Hence, the null hypothesis of a unit root is rejected (Type 1 Error) against the one-sided alternative if the t-statistics is less than the critical value.

$$
\begin{gathered}
\mathrm{INTt}=\alpha \mathrm{iINFt}-\mathrm{i}+\mathrm{Vt} \\
\mathrm{GCFt}=\lambda \mathrm{iGDPt}-\mathrm{i}+\mathrm{V} 1 \mathrm{t}
\end{gathered}
$$

Where

$\triangle=\quad$ First difference operator

Gcf $=$ Gross Capital formation

INT $=$ Interest rate

GDP $=$ Gross Domestic Product

$\mathrm{t}-\mathrm{i}$ and $\mathrm{t}-\mathrm{j}=$ Lag values

$\alpha i$ and $\lambda i$ are estimated coefficient lagged INF and GDP in equation (10) and (11) respectively.

$V_{t}$ and $V_{i t}$ are disturbance error term.

From equation (10), if $\alpha \mathrm{i}=0$, interest rate is non-stationary and also equation (11), where $\lambda \mathrm{i}=0$ inflation rate will be non-stationarity, while time series on explanatory variables are integrated order I (1). Also, where outcomes of interest rate and capital formation as well as Interest Rate and Inflation Rate are not co-integrated as shown in equation (10) and (11) above, therefore $\alpha \mathrm{i}$ and $\lambda \mathrm{i}$ are significantly different from zero (individually integrated). Recall, the regression of a non-stationarity time series on another non-stationary time series may produce a spurious regression. Therefore, it is essential to affirm whether the variables can be co-integrated by carrying out configuration test. A linear relationship of two or more no-stationary series, which may be stationary. Where such a stationary that is, I (o), a linear relationship exists, the non-stationary that is, I (1) however, with a unit root), therefore time series are expected to be co-integrated[49]. The stationary linear relationship is called co-integrating equation and explained as a stable long-run relationship among the non-stationarity time series variables. In addition, the short-run dynamics that might cause the relationship not to be established in the short-run. Though, the co-integration test can be conducted through Engle and Granger (1987) - Augmented Engle - Granger (AEG) test. In this situation two-step test and maximum likelihood method developed [50,51].

The Error Correction Mechanism (ECM) was developed by means of reconciling the dynamism of the short-run and long-run economic variable behavior. However, in the short-run there may be disequilibrium. It is believed that in the long-run, there would be equilibrium or relationship between Interest Rate and Inflation rate, as well as capital formation and gross domestic product could be ascertained. Being individually non-stationary, a linear combination of two or more time series can be stationary. The Engle Granger, Augmented Engle-Granger and Co-integrating Regression Durbin Watson test can be used to find out if two or more time series are co-integrated[49]. 
However, due to the ability of ECM to induce flexibility by combining both the short-run and long-run dynamism in a united system. Also the estimates of the parameters of Error Correction Mechanism (ECM) are generally consistent, sufficient, significant and negative. The non-zero coefficient of $\Delta \mathrm{INT}_{\mathrm{t}}$ and $\mathrm{INF}_{\mathrm{t}}$ in both ways, if statistically significant, will indicate a short-run causality from $\Delta \mathrm{INT}_{\mathrm{t}}$ to $\Delta \mathrm{Gcf}_{\mathrm{t}}$ as well as $\Delta \mathrm{INFt}$ to $\Delta \mathrm{GDP}_{\mathrm{t}}$. The statistically significant non-zero coefficients of $\Delta \mathrm{Gcf}_{\mathrm{t}}$ as well as $\Delta \mathrm{GDP}_{\mathrm{t}}$ will indicate bi-causality or feedback to $\Delta \mathrm{Gcf}_{\mathrm{t}}$ as well as $\Delta \mathrm{GDP}_{\mathrm{t}}$ from its own lagged values respectively. It must be noted that where there is no co-integration, the error correction model may be estimated.

\section{Empirical Result}

Regression result in model (i), equation 2 is $\mathrm{Gcf}=-79.2-$ 18.5 INF; $\mathrm{t}=(-2.801)(-2.4) ; \mathrm{R} 2=0.73$; D-Watson Statistics $=0.33 ; \mathrm{f}-$ statistics $43.5, \mathrm{f} 0.05=3.32$. The result shows that the two variables i.e. dependent and independent variables are statistically related. The economic implication of the rightly signed parameter is that an increase in the gross capital formation will surely beef-up the activities of the real output (GDP), though, too much capital formation in circulation might be dangerous economically, because it may lead to idle funds. An increase of capital will have a positive impact on the economy, the study has a reasonable goodness of fit i.e. the variation in GDP is being explained by about $73 \%$ in the independent variables. This shows the statistical relevance of the study. The Nigerian economic growth has a significant effect on the capital formation; f-statistics of 43.5 shows the overall significance and influence the activities of the real output positively as long as the interest rate remains low; while in model (ii), equation 3 , the result explained that $\mathrm{Gcf}=-12.3-58.8 \mathrm{GDP} ; \mathrm{t}=(-3.9)(-0.62) ; \mathrm{R} 2=0.69 ; \mathrm{D}$ - Watson Statistics $=0.114 ; \mathrm{f}-$ statistics 35.2, f $0.05=$ 3.32.The coefficient of GDP in this equation is negatively signed indicating an indirect non- linear relationships between GCF and GDP. The coefficients of determination (R2) is at $69 \%$. More so, at $5 \%$ level of significance of the time trend, the study is statistically useful because of the magnitude of the t-calculated of (5.157) compare with the $\mathrm{t}$-tabulated. The economic policy implication of the aforesaid analysis, is that if monetary policy is properly formulated an implemented, there will be a positive impact on the overall economy. The f-statistic (Econometric criterion tool) stipulates the relevance of monetary policy of the economy. The value of the f-statistics of (35.2) is greater than the f-tabulated at $5 \%$ level of significance. Model (iii), equation 4 , result shows, $=-25.4-14.8 \mathrm{INT} ; \mathrm{t}=(-1.55)(-9.7) ; \mathrm{R} 2=$ 0.92 ; D -Watson Statistics $=0.824 ; \mathrm{f}-$ statistics $82.584 ; \mathrm{f}$ $0.05=3.36$. This is a linear equation where Gross Capital Formation (GCF) is being handled as the dependent variable with interest rate in the explanatory variable. The focus is to really determine the worthwhile of interest rate targeting in Nigeria. The result shows that the variable in question are statistically and economically related. The coefficient of determination (R2) measures a very reasonable goodness of fit at $92.2 \%$ this shows that the change in interest rate is being caused by the $75 \%$ change in the Gross Capital Formation. At 5\% level of significance, the result shows that the study is statistically significant, therefore, there is a relationship between Gross Capital Formation (GCF) and interest rate in a reform economy to ensure overall economic growth; the overall study is being shown by the f-statistics of (91.03). The final Model (iv), equation 5, result is $=-37.0+$ 64.1INF - 64.4GDP - 15.1INT; $\mathrm{t}=(-2.1)(-1.25)(-1.23)$ $(-8.82) ; \mathrm{R} 2=0.922 ; \mathrm{f}-$ statistics 91.03 ; f $0.05=3.36$; D Watson Statistics $=0.69$. It shows that multiple equation regresses the Gross Capital Formation (GCF) against three explanatory variables- inflation, Gross Domestic Product and interest rate. The result reveals that the three variables explain the variation in the inflation, GDP and interest rate as the coefficient of the explanatory variables comes out positive considering the time trend. The positive signs indicate that the parameters are coefficients positively and directly related. The goodness of fit of $92 \%$ show that the variation in the Gross Capital Formation accounted for by the $92 \%$ variation in the explanatory variables. The t-ratio of all the explanatory variables suggested that the study is significant since t-calculated of (11.01) considering the time trend is greater than the t-tabulated of 3.32. Conclusively, the study is generally related as shown by the coefficient of the parameter and significant to all the explanatory variables. The Durbin Watson coefficient of 0.69 shows that there is some element of auto-correlation in the D-Watson, when is less than 2 .

Figure 1, table 1-7 below explained the interest rate variable which show statistical significant relationship among one another. In order to derive a logical conclusion, among all the interest rate variables, which include demand deposit rate (DDR), Deposit Money Banks (DMB), Lending Rate (LR), Monetary Policy Rate (MPR), Savings Deposit (SD), Treasury Bill (TB) and Time Deposit Rate (TDR), for the purpose of this study, it was only the savings deposit that best capture the most needed interest rate for this research work. This is shown in table 6 . It must be noted that it has the highest $\mathrm{R} 2=31 \%$ above other variables with best minimum. AIC and SIC of 27.89 and 27.98, which shows the extent on how insignificant variables are removed to the minimum. But with a low DW of 0.26 which is far and less from 2. This shows auto correlation on the explanatory variable also with a high significant probability of 0.0018 less than the significant level of $5 \%$. This result has shown that there is an increase in savings deposit rates reflected essentially enhanced competition in the banking system, following the recent financial and economic reform in the country. The empirical evidence has shown that most bank customers operate savings account with their customers at acceptable interest rate.

In the pairwise Granger Causality Test table 9-10 above F-statistics with 1-year and 2-year time lags were calculated for an emerging market: Nigeria. It is based on time series 
data from 1970-2010. The results as evidenced from F-values indicate a unidirectional causality from capital formation to interest rate at $5 \%$ level of significance whereas the hypothesis that causality is unidirectional from interest rate to Gross Capital formation is rejected. Theoretically, the unidirectional shows that the estimated coefficients on the lagged Gcf are statistically different from zero i.e. $\alpha \mathrm{i} \neq \mathrm{o}$ and the set of estimated coefficients on the lagged INT is not statistically different from zero i.e $(\delta \mathrm{j}=0)$ [49]. This however shows that 'bilateral or feedback' from interest rate to Gross capital formation is not supported by the result of this study. Therefore, Gross Capital Formation (GCF) causes Interest Rate (INT) but interest rate (INT) does not cause Gross capital formation (GCF) during the guided interest rate regime. This actually may result to the recent economic reform in the banking sub-sector in 2005 and 2011 during the banks' recapitalization and recent shake -up in Nigerian banking sub-sector respectively. Hence, this may be as a result of its sensitiveness to the changes in lag length.

Table 11 and 12 under figure 3 below show the time series behaviour of each series as presented earlier using the Augmented Dickey-Fuller (ADF) and Phillips-Perron (PP) test show over-whelming proof of the existence of non-stationarity (differencing the non-stationarity) in the series and that the variables are integrated of order 1(1) as shown in the decision 'column'. Though, both the ADF and PP test show that the null of non-stationarity will be rejected (Type 1 error) for all the variable at levels.

With table 13 below, which shows the co-integration test, which are conducted according to rank tests. The trace statistics suggest the existence of only one co-integrating at the $5 \%$ critical value and the test indicates co-integration at the $1 \%$ critical value for the model, as shown;

This further explains that non-stationarity time series on explanatory variables; I (I) with linear combination or relationship in stationary time series; I (0) could only be co-integrated at $1 \%$ and 5\%.To ascertain for co-integration between the contemporaneous financial sectors variables in levels, the long-run of interest rate on capital formation which exists in emerging market is estimated by the model in table 14 below.

The model shows that explanatory variables are quite able to explain the variations during the guided interest rate regime. However, the explanatory variables are estimated at $74.0 \%$ variations in the proxies for increase in Gross Capital formation during the guided interest rate regime/post-reform era more than in unregulated and regulated interest rate regime (pre-reform era). The Pre-reform era represents zero (o) while post reform era represents one (1). With the Gross Capital Formation (GCF) with higher values of adjusted $\mathrm{R}^{2}$ i.e. $74.0 \%$. However, the high values of F-statistics in the model indicate a significance of the explanatory variables. But the estimated coefficient of interest rate is negative with a very low Durbin Watson. But the long-run model shows that only Gross Capital Formation (GCF) is significant in explaining the guided interest rate regime / post reform era. Level of Capital Formation during guided interest rate regime always show how monetary policy implementation framework will remove volatility in inter-bank rates and improve the transmission of monetary policy actions $[52,56]$.

With reference to the results on the co-integration test, over-parameterized interest rate in the emerging market was estimated. Every variable was set at one (1) lag. To commence with over-parameterized models as stated in Error Correction Mechanism table 15-18 below:

However, which is then tested down until the preferred parsimonious models as stated in table 16 (Error Correction Mechanism - B) is derived at. The parsimonious encompassing models explained that based on Akaike Info Criterion (AIC) or Schiwarz Info Criterion (SIC), the re-parameterize model ensures that insignificant variables are excluded until Information Criterion (IC) start rising as depicted in table 16. In order to ascertain a goodness of fit test, the models that emerged is slightly significant to the over-parameterized ones. The dynamic parsimonious result for model, it shows that the explanatory variables accounted for $20.3 \%$ variations in the level over the entire sample period. The findings show that $43.6 \%$ errors are corrected yearly. Though the Error Correction Term (ECT) must be negative and significant.

\section{Conclusion}

The paper examines interest rate impact on economic growth in Nigeria, considering the stakeholders' approach. Findings show that interest rate is invariant with respect to changes in anticipated inflation and it remains one of the economic tools to stimulate economic growth. The study shows that interest rate will automatically assist in the mobilization and utilization process of financial resources to achieve a desired economic growth, but the administered structure of interest rate is weak in Nigeria. Further result from the study depicts that there is a significant interest rate impact on economic growth in Nigeria, and a long-term relationship exists between interest rate and economic growth. The current private sector investments should be directed more to labor intensive projects rather than capital intensive so that unemployment could be reduced drastically to promote economic growth. The government should encourage public-private programmes as an initiative to promote economic growth particularly in the area of infrastructural and socio-economic activities. The Nigerian government should re-examine and improve on the incentives structure by making investment available in labor intensive projects in area of agriculture, manufacturing, small scale enterprises and easy access to loan should be $0-6 \%$ interest rate charged by banks. Obviously, labor is very cheap in Nigeria; the present and future economic growth and development largely depends on comparative low labor cost to reduce the high level of unemployment.There is need to pursue to a logical end in order to boost and encourage private sector confidence that will show that Nigerian economy is indeed pursuing private sector-led economic 
policies by reducing the interest rate to a single digit. The current economic reforms are desirable and should be sustained. A well-developed financial market and banks are prerequisite for the use of interest rate as a major monetary instrument. Our financial market will be efficient only if government controls prices in the market such as interest rates and transaction fees. The high interest rate will lead to excess liquidity which may result into unnecessary credit expansion.Therefore, the wide spread between deposit and lending rates should be controlled and actively managed. The result shows that the increase in interest rate may lead to increase in inflation, high cost of funds, increasing in domestic debts, weaker exchange rate, rising unemployment rate in Nigeria. There is need of strong capital account policy to regulate short- term capital flow and exchange rate volatility. There is need for Nigerian government to reduce the syndrome of continuous external borrowing financing from international financial institutions (e.g. World Bank, International Monetary Funds - IMF, Paris Club etc.) because it may attract high interest rate, which has a negative implications on the whole economy. There is need for discipline, accountability and transparency of policy makers in order to create friendly financial environment for investors.
The Central Bank of Nigeria (CBN) should ensure the stabilization of the financial markets and banks in order to control and manage risk aversion among national and international investors in the economy. CBN and NDIC should formulate policies and initiatives to re-position the market in order to actively play its roles in the development of the Nigerian economy. The paper further recommends non-stopping reforms in the monetary sector in order to serve as check and balances so as to manage and control interest rates trend in the country. Policymakers - Monetary Policy Committee and regulatory government agencies - CBN, NDIC, etc. via the Ministry of Finance should adopt economic policies - interest rate policies that can strengthen, and promote allocation of efficient resources to achieve economic growth.

\section{Acknowledgement}

I will like to appreciate Central Bank of Nigeria (CBN) for the data used in the study. Also, Mr. \& Mrs. Adetoro Suleiman for the professional advice, moral and financial support.

\section{Appendix 1}

\section{Regression}

\section{Variables Entered/Removed b}

\begin{tabular}{|l|l|l|l|}
\hline Model & $\begin{array}{l}\text { Variables } \\
\text { Entered }\end{array}$ & $\begin{array}{c}\text { Variables } \\
\text { Removed }\end{array}$ & Method \\
\hline 1 & $\begin{array}{l}\text { Time } \\
\text { trend, a } \\
\text { Inflation }\end{array}$ & & Enter \\
\hline
\end{tabular}

a. All requested variables entered.

b. Dependent Variable: Gross capital formation

\begin{tabular}{|c|c|c|c|c|c|}
\hline \multicolumn{6}{|c|}{ Model Summary } \\
\hline Model & $\mathrm{R}$ & R Square & $\begin{array}{l}\text { Adjusted } \\
R \text { Square }\end{array}$ & $\begin{array}{l}\text { Std. Error of } \\
\text { the Estimate }\end{array}$ & $\begin{array}{l}\text { Durbin- } \\
\text { Watson }\end{array}$ \\
\hline 1 & $.851^{a}$ & .725 & .708 & 74073103.2 & .333 \\
\hline
\end{tabular}

a. Predictors: (Constant), Time trend, Inflation

b. Dependent Variable: Gross capital formation 


\section{Coefficients}

\begin{tabular}{|c|c|c|c|c|c|c|}
\hline \multirow{2}{*}{\multicolumn{2}{|c|}{ Model }} & \multicolumn{2}{|c|}{ Unstandardized Coefficients } & \multirow{2}{*}{$\begin{array}{c}\begin{array}{c}\text { Standardized } \\
\text { Coefficients }\end{array} \\
\text { Beta }\end{array}$} & \multirow[b]{2}{*}{$\mathrm{t}$} & \multirow[b]{2}{*}{ Sig. } \\
\hline & & B & Std. Error & & & \\
\hline \multirow[t]{3}{*}{1} & (Constant) & -78462858.207 & $3 E+007$ & & -2.801 & .008 \\
\hline & Inflation & -1787874.545 & 747974.0 & -.220 & -2.390 & .023 \\
\hline & Time trend & 11117206.112 & 1200455 & .854 & 9.261 & .000 \\
\hline
\end{tabular}

a. Dependent Variable: Gross capital formation

Va riables Entered/Re movkd

\begin{tabular}{|l|l|l|l|}
\hline Model & $\begin{array}{c}\text { Variables } \\
\text { Entered }\end{array}$ & $\begin{array}{c}\text { Variables } \\
\text { Removed }\end{array}$ & Method \\
\hline 1 & $\begin{array}{c}\text { Time } \\
\text { trend, GDP }\end{array}$ & & Enter \\
\hline
\end{tabular}

a. All requested variables entered.

b. Dependent Variable: Gross capital formation

\begin{tabular}{|l|r|r|r|r|r|}
\multicolumn{7}{|c|}{ Model Summary } \\
\hline Model & $\mathrm{R}$ & R Square & $\begin{array}{c}\text { Adjusted } \\
\text { R Square }\end{array}$ & $\begin{array}{c}\text { Std. Error of } \\
\text { the Estimate }\end{array}$ & $\begin{array}{c}\text { Durbin- } \\
\text { Watson }\end{array}$ \\
\hline 1 & $.825^{\mathrm{a}}$ & .681 & .662 & 79768822.4 & .114 \\
\hline
\end{tabular}

a. Predictors: (Constant), Time trend, GDP

b. Dependent Variable: Gross capital formation

Coefficientş

\begin{tabular}{|c|c|c|c|c|c|c|}
\hline \multirow{2}{*}{\multicolumn{2}{|c|}{ Model }} & \multicolumn{2}{|c|}{ Unstandardized Coefficients } & \multirow{2}{*}{$\begin{array}{c}\begin{array}{c}\text { Standardized } \\
\text { Coefficients }\end{array} \\
\text { Beta } \\
\end{array}$} & \multirow[b]{2}{*}{$\mathrm{t}$} & \multirow[b]{2}{*}{ Sig. } \\
\hline & & B & Std. Error & & & \\
\hline \multirow[t]{3}{*}{1} & (Constant) & -115073347.296 & $3 E+007$ & & -3.874 & .000 \\
\hline & GDP & -58.839 & 95.156 & -.110 & -.618 & .541 \\
\hline & Time trend & 11898728.695 & 2307177 & .914 & 5.157 & .000 \\
\hline
\end{tabular}

a. Dependent Variable: Gross capital formation 


\section{Variables Entered/Removed ${ }^{b}$}

\begin{tabular}{|l|l|l|l|}
\hline Model & $\begin{array}{l}\text { Variables } \\
\text { Entered }\end{array}$ & $\begin{array}{c}\text { Variables } \\
\text { Removed }\end{array}$ & Method \\
\hline 1 & $\begin{array}{l}\text { Time } \\
\text { trend, } \\
\text { Interest } \\
\text { rate }\end{array}$ & & Enter \\
\hline
\end{tabular}

a. All requested variables entered.

b. Dependent Variable: Gross capital formation

\begin{tabular}{|l|r|r|r|r|c|}
\multicolumn{7}{|c|}{ Model Summary } \\
\hline Model & \multicolumn{1}{|c|}{ R } & R Square & $\begin{array}{c}\text { Adjusted } \\
\text { R Square }\end{array}$ & $\begin{array}{c}\text { Std. Error of } \\
\text { the Estimate }\end{array}$ & $\begin{array}{c}\text { Durbin- } \\
\text { Watson }\end{array}$ \\
\hline 1 & $.957^{\text {a }}$ & .916 & .911 & 41018280.0 & .824 \\
\hline
\end{tabular}

a. Predictors: (Constant), Time trend, Interest rate

b. Dependent Variable: Gross capital formation

Coefficients

\begin{tabular}{|c|c|c|c|c|c|c|}
\hline \multirow[b]{2}{*}{ Model } & & \multicolumn{2}{|c|}{ Unstandardized Coefficients } & \multirow{2}{*}{$\begin{array}{c}\begin{array}{c}\text { Standardized } \\
\text { Coefficients }\end{array} \\
\text { Beta } \\
\end{array}$} & \multirow[b]{2}{*}{$\mathrm{t}$} & \multirow[b]{2}{*}{ Sig. } \\
\hline & & B & Std. Error & & & \\
\hline \multirow[t]{3}{*}{1} & (Constant) & -25306185.362 & $2 \mathrm{E}+007$ & & -1.547 & .131 \\
\hline & Interest rate & -13840505.826 & 1433275 & -.504 & -9.657 & .000 \\
\hline & Time trend & 12318916.446 & 678806.0 & .946 & 18.148 & .000 \\
\hline
\end{tabular}

a. Dependent Variable: Gross capital formation

Va riables Entere d/Re moved

\begin{tabular}{|l|l|l|l|}
\hline Model & $\begin{array}{l}\text { Variables } \\
\text { Entered }\end{array}$ & $\begin{array}{c}\text { Variables } \\
\text { Removed }\end{array}$ & Method \\
\hline 1 & $\begin{array}{l}\text { Time } \\
\text { trend, } \\
\text { Inflation, } \\
\text { Interest a } \\
\text { rate, GDP }\end{array}$ & & \\
& & & \\
\hline
\end{tabular}

a. All requested variables entered.

b. Dependent Variable: Gross capital formation

Model Summary ${ }^{b}$

\begin{tabular}{|l|r|r|r|r|r|}
\hline Model & \multicolumn{1}{|c|}{ R } & R Square & $\begin{array}{c}\text { Adjusted } \\
\text { R Square }\end{array}$ & $\begin{array}{c}\text { Std. Error of } \\
\text { the Estimate }\end{array}$ & $\begin{array}{c}\text { Durbin- } \\
\text { Watson }\end{array}$ \\
\hline 1 & $.960^{\mathrm{a}}$ & .922 & .911 & 40814273.1 & .693 \\
\hline
\end{tabular}

a. Predictors: (Constant), Time trend, Inflation, Interest rate, GDP

b. Dependent Variable: Gross capital formation 
Coefficients $^{a}$

\begin{tabular}{|c|c|c|c|c|c|c|}
\hline \multirow{2}{*}{\multicolumn{2}{|c|}{ Model }} & \multicolumn{2}{|c|}{ Unstandardized Coefficients } & \multirow{2}{*}{$\begin{array}{c}\begin{array}{c}\text { Standardized } \\
\text { Coefficients }\end{array} \\
\text { Beta }\end{array}$} & \multirow[b]{2}{*}{$\mathrm{t}$} & \multirow[b]{2}{*}{ Sig. } \\
\hline & & $B$ & Std. Error & & & \\
\hline \multirow[t]{5}{*}{1} & (Constant) & -37381203.018 & $2 \mathrm{E}+007$ & & -2.049 & .049 \\
\hline & Inflation & 642183.095 & 513848.1 & .079 & 1.250 & .221 \\
\hline & GDP & -64.404 & 51.714 & -.120 & -1.245 & .222 \\
\hline & Interes t rate & -14941420.131 & 1695237 & -.544 & -8.814 & .000 \\
\hline & Time trend & 13600407.035 & 1235505 & 1.045 & 11.008 & .000 \\
\hline
\end{tabular}

a. Dependent Variable: Gross capital formation

\section{Appendix 2}

\section{The Capturing Of Interest Rate}

Table 1. Demand Deposit Rate (DDR)

Dependent Variable: GCF

Method: Least Squares

Sample: 1970 - 2010

Included observations: 40

\begin{tabular}{ccccc}
\hline \hline Variable & Coefficient & Std. Error & t-Statistic & Prob. \\
\hline \hline C & 419366.6 & 153542.9 & 2.731266 & 0.0116 \\
DDR & -15852.82 & 10907.29 & -1.453415 & 0.1591 \\
\hline \hline R-squared & 0.080897 & Mean dependent var & 214706.7 \\
Adjusted R-squared & 0.042601 & S.D. dependent var & 318998.2 \\
S.E. of regression & 312129.5 & Akaike info criterion & 28.21403 \\
Sum squared resid & $2.34 \mathrm{E}+12$ & Schwarz criterion & 28.31080 \\
Log likelihood & -364.7824 & F-statistic & 2.112415 \\
Durbin-Watson stat & 0.212061 & Prob(F-statistic) & 0.159061 \\
\hline \hline
\end{tabular}

Table 2. Deposit Money Banks (DMB)

Dependent Variable: GCF

Method: Least Squares

Sample: 1970 - 2010

Included observations: 40

\begin{tabular}{ccccc}
\hline \hline Variable & Coefficient & Std. Error & t-Statistic & Prob. \\
\hline \hline C & 403225.9 & 159589.4 & 2.526646 & 0.0185 \\
DMB & -14333.02 & 11187.67 & -1.281145 & 0.2124 \\
\hline \hline R-squared & 0.064011 & Mean dependent var & 214706.7 \\
Adjusted R-squared & 0.025012 & S.D. dependent var & 318998.2 \\
S.E. of regression & 314983.6 & Akaike info criterion & 28.23223 \\
Sum squared resid & $2.38 \mathrm{E}+12$ & Schwarz criterion & 28.32901 \\
Log likelihood & -365.0190 & F-statistic & 1.641332 \\
Durbin-Watson stat & 0.149291 & Prob(F-statistic) & 0.212384 \\
\hline \hline
\end{tabular}


Table 3. Interest Rate (LR)

Dependent Variable: GCF

Method: Least Squares

Sample: 1970 - 2010

Included observations: 40

\begin{tabular}{ccccc}
\hline \hline Variable & Coefficient & Std. Error & t-Statistic & Prob. \\
\hline \hline C & -92006.98 & 210716.6 & -0.436639 & 0.6663 \\
INT & 15670.49 & 10305.17 & 1.520644 & 0.1414 \\
\hline \hline R-squared & 0.087881 & Mean dependent var & 214706.7 \\
Adjusted R-squared & 0.049876 & S.D. dependent var & 318998.2 \\
S.E. of regression & 310941.3 & Akaike info criterion & 28.20640 \\
Sum squared resid & $2.32 \mathrm{E}+12$ & Schwarz criterion & 28.30318 \\
Log likelihood & -364.6832 & F-statistic & 2.312359 \\
Durbin-Watson stat & 0.223603 & Prob(F-statistic) & 0.141416 \\
\hline \hline
\end{tabular}

Table 4. Lending Rate (LR).

Dependent Variable: GCF

Method: Least Squares

Sample: 1970 -2010

Included observations: 40

\begin{tabular}{ccccc}
\hline \hline Variable & Coefficient & Std. Error & t-Statistic & Prob. \\
\hline \hline C & 88176.12 & 179784.3 & 0.490455 & 0.6283 \\
LR & 6968.431 & 9271.145 & 0.751626 & 0.4596 \\
\hline \hline R-squared & 0.022998 & Mean dependent var & 214706.7 \\
Adjusted R-squared & -0.017711 & S.D. dependent var & 318998.2 \\
S.E. of regression & 321810.7 & Akaike info criterion & 28.27512 \\
Sum squared resid & $2.49 \mathrm{E}+12$ & Schwarz criterion & 28.37189 \\
Log likelihood & -365.5765 & F-statistic & 0.564941 \\
Durbin-Watson stat & 0.154330 & Prob(F-statistic) & 0.459584 \\
\hline \hline
\end{tabular}

Table 5. Monetary Policy Rate (MPR).

Dependent Variable: GCF

Method: Least Squares

Sample: 1970 - 2010

Included observations: 40

\begin{tabular}{ccccc}
\hline \hline Variable & Coefficient & Std. Error & t-Statistic & Prob. \\
\hline \hline C & 56730.20 & 207295.6 & 0.273668 & 0.7867 \\
MPR & 11574.35 & 14469.01 & 0.799941 & 0.4316 \\
\hline \hline R-squared & 0.025970 & Mean dependent var & 214706.7 \\
Adjusted R-squared & -0.014614 & S.D. dependent var & 318998.2 \\
S.E. of regression & 321320.7 & Akaike info criterion & 28.27207 \\
Sum squared resid & $2.48 \mathrm{E}+12$ & Schwarz criterion & 28.36885 \\
Log likelihood & -365.5369 & F-statistic & 0.639905 \\
Durbin-Watson stat & 0.159682 & Prob(F-statistic) & 0.431592 \\
\hline \hline
\end{tabular}


Table 6. Savings Deposit (SD)

Dependent Variable: GCF

Method: Least Squares

Sample: 1970 - 2010

Included observations: 40

\begin{tabular}{ccccc}
\hline \hline Variable & Coefficient & Std. Error & t-Statistic & Prob. \\
\hline \hline C & 587415.4 & 118367.4 & 4.962645 & 0.0000 \\
SD & -39164.31 & 11176.97 & -3.504019 & 0.0018 \\
\hline \hline R-squared & 0.338445 & Mean dependent var & 214706.7 \\
Adjusted R-squared & 0.310880 & S.D. dependent var & 318998.2 \\
S.E. of regression & 264810.8 & Akaike info criterion & 27.88522 \\
Sum squared resid & $1.68 \mathrm{E}+12$ & Schwarz criterion & 27.98200 \\
Log likelihood & -360.5079 & F-statistic & 12.27815 \\
Durbin-Watson stat & 0.267186 & Prob(F-statistic) & 0.001824 \\
\hline \hline
\end{tabular}

Table 7. Treasury Bill (TB)

Dependent Variable: GCF

Method: Least Squares

Sample: 1970 -2010

Included observations: 40

\begin{tabular}{ccccc}
\hline \hline Variable & Coefficient & Std. Error & t-Statistic & Prob. \\
\hline \hline C & 100399.8 & 176829.6 & 0.567777 & 0.5755 \\
TB & 8898.148 & 12855.30 & 0.692178 & 0.4955 \\
\hline \hline R-squared & 0.019572 & Mean dependent var & 214706.7 \\
Adjusted R-squared & -0.021279 & S.D. dependent var & 318998.2 \\
S.E. of regression & 322374.3 & Akaike info criterion & 28.27862 \\
Sum squared resid & $2.49 \mathrm{E}+12$ & Schwarz criterion & 28.37539 \\
Log likelihood & -365.6220 & F-statistic & 0.479110 \\
Durbin-Watson stat & 0.161387 & Prob(F-statistic) & 0.495469 \\
\hline \hline
\end{tabular}

Table 8. Time Deposit Rate (TDR).

Dependent Variable: GCF

Method: Least Squares

Sample: 1970- 2010

Included observations: 40

\begin{tabular}{ccccc}
\hline \hline Variable & Coefficient & Std. Error & t-Statistic & Prob. \\
\hline \hline C & 362441.6 & 171289.1 & 2.115964 & 0.0449 \\
TDR & -11429.82 & 12331.25 & -0.926899 & 0.3632 \\
\hline \hline R-squared & 0.034560 & Mean dependent var & 214706.7 \\
Adjusted R-squared & -0.005666 & S.D. dependent var & 318998.2 \\
S.E. of regression & 319900.7 & Akaike info criterion & 28.26321 \\
Sum squared resid & $2.46 \mathrm{E}+12$ & Schwarz criterion & 28.35999 \\
Log likelihood & -365.4218 & \multicolumn{2}{c}{ F-statistic } & 0.859142 \\
Durbin-Watson stat & 0.134642 & Prob(F-statistic) & 0.363207 \\
\hline \hline
\end{tabular}




\section{Granger Causality Test}

Table 9. Pairwise Granger Causality Tests - 2A

Pairwise Granger Causality Tests

Sample: $1970-2010$

Lags: 2

Null Hypothesis

LNINTR does not Granger Cause LNGCF

LNGCF does not Granger Cause LNINTR

Pairwise Granger Causality Tests Sample: 1970 - 2010

Lags: 2

Null Hypothesis

LNINTR does not Granger Cause LNGCF

LNINTR does not Granger Cause LNGCF
Obs

F-Statistic

40

3.28500

5.53597

0.00920

Probability

0.05177
Table 10. Pairwise Granger Causality Tests $-2 \mathrm{~B}$

Obs

F-Statistic

Probability

40

0.08168

0.92178

2.01533

\section{Augmented Dickey Fuller (Adf) Unit Root Test}

Table 11. Augmented Dickey Fuller - ADF.(1st difference)-3A

\begin{tabular}{|c|c|c|c|c|c|c|c|}
\hline Variable & $\begin{array}{c}\text { Intercept or } \\
\text { constant }\end{array}$ & $\begin{array}{c}\text { Intercept and } \\
\text { trend }\end{array}$ & None & $\begin{array}{c}\text { Intercept or } \\
\text { constant }\end{array}$ & $\begin{array}{c}\text { Intercept and } \\
\text { trend }\end{array}$ & None & Decision \\
\hline Log Gcf & 1.43 & -2.4 & 9.7 & -2.9 & -3.8 & -0.79 & $\mathrm{I}(1)$ \\
\hline Log SD & -0.51 & -1.5 & -0.6 & -4.9 & -5.9 & -5.0 & $\mathrm{I}(1)$ \\
\hline Critical & $1 \%--3.7$ & $1 \%--4.4$ & $1 \%=-2.7$ & $1 \%=-3.8$ & $1 \%=-4.5$ & $1 \%=-2.7$ & \\
Value & $5 \%=-2.99$ & $5 \%=-3.6$ & $5 \%=-1.96$ & $5 \%=-3.01$ & $5 \%=-3.6$ & $5 \%=-1.96$ & \\
\hline
\end{tabular}

\section{Phillips - Perron (Pp) Test}

Table 12. Phillips - Perron (PP) Test. (1st difference)-3B

\begin{tabular}{|c|c|c|c|c|c|c|c|}
\hline Variable & $\begin{array}{c}\text { Intercept or } \\
\text { constant }\end{array}$ & $\begin{array}{c}\text { Intercept and } \\
\text { trend }\end{array}$ & None & $\begin{array}{c}\text { Intercept or } \\
\text { constant }\end{array}$ & $\begin{array}{c}\text { Intercept and } \\
\text { trend }\end{array}$ & None & Decision \\
\hline Log Gcf & 2.6 & -1.8 & 16.2 & -2.8 & -3.1 & -0.4 & $\mathrm{I}(1)$ \\
\hline Log SD & -0.5 & -1.4 & -0.6 & -4.9 & -5.9 & -5.01 & $\mathrm{I}(1)$ \\
\hline Critical & $1 \%--3.7$ & $1 \%--4.4$ & $1 \%=-2.7$ & $1 \%=-3.8$ & $1 \%=-4.5$ & $1 \%=-2.7$ & \\
Value & $5 \%=-2.99$ & $5 \%=-3.6$ & $5 \%=-1.96$ & $5 \%=-3.01$ & $5 \%=-3.6$ & $5 \%=-1.96$ & \\
\hline
\end{tabular}


Table 13. Co-integration Test

Sample (adjusted): 1970- 2010

Included observations: 39 after adjusting endpoints

Trend assumption: No deterministic trend (restricted constant)

Series: LNGDP LNCPI

Lags interval (in first differences): No lags

Unrestricted Cointegration Rank Test

\begin{tabular}{ccccc}
\hline $\begin{array}{c}\text { Hypothesized } \\
\text { No. of CE(s) }\end{array}$ & Eigenvalue & Statistic & C Percent \\
Critical Value & Critical Value \\
\hline None ${ }^{* *}$ & 0.685960 & 48.43877 & 19.96 & 24.60 \\
At most 1 & 0.202067 & 7.900591 & 9.24 & 12.97 \\
\hline
\end{tabular}

$*(* *)$ denotes rejection of the hypothesis at the $5 \%(1 \%)$ level

Trace test indicates 1 cointegrating equation(s) at both $5 \%$ and $1 \%$ levels

\begin{tabular}{ccccc}
\hline Hypothesized & Max-Eigen & 5 Percent & 1 Percent \\
No. of CE(s) & Eigenvalue & Statistic & Critical Value & Critical Value \\
None $* *$ & 0.685960 & 40.53818 & 15.67 & 20.20 \\
At most 1 & 0.202067 & 7.900591 & 9.24 & 12.97 \\
\hline
\end{tabular}

$*(* *)$ denotes rejection of the hypothesis at the $5 \%(1 \%)$ level

Max-eigenvalue test indicates 1 cointegrating equation(s) at both $5 \%$ and $1 \%$ levels 
Table 14. Long-Run Model

Dependent Variable: LNGDP

Method: Least Squares

Sample: 1970 - 2010

Included observations: 40

\begin{tabular}{|c|c|c|c|c|}
\hline Variable & Coefficient & Std. Error & $\mathrm{t}$-Statistic & Prob. \\
\hline $\mathrm{C}$ & 10.83179 & 0.061157 & 177.1133 & 0.0000 \\
\hline LNCPI & 0.103962 & 0.010362 & 10.03293 & 0.0000 \\
\hline R-squared & 0.747512 & \multicolumn{2}{|c|}{ Mean dependent var } & 11.40224 \\
\hline Adjusted R-squared & 0.740086 & \multicolumn{2}{|c|}{ S.D. dependent var } & 0.265089 \\
\hline S.E. of regression & 0.135147 & \multicolumn{2}{|c|}{ Akaike info criterion } & -1.110954 \\
\hline Sum squared resid & 0.621000 & \multicolumn{2}{|c|}{ Schwarz criterion } & -1.022981 \\
\hline Log likelihood & 21.99718 & \multicolumn{2}{|c|}{ F-statistic } & 100.6597 \\
\hline Durbin-Watson stat & 0.807981 & \multicolumn{2}{|c|}{ Prob(F-statistic) } & 0.000000 \\
\hline
\end{tabular}

Table 15. Error Correction Mechanism - A

Dependent Variable: D(LNGDP)

Method: Least Squares

Sample(adjusted): 1970- 2010

Included observations: 38 after adjusting endpoints

\begin{tabular}{|c|c|c|c|c|}
\hline Variable & Coefficient & Std. Error & t-Statistic & Prob. \\
\hline $\mathrm{C}$ & 0.047916 & 0.042634 & 1.123878 & 0.2713 \\
\hline $\mathrm{D}(\mathrm{LNCPI})$ & -0.159367 & 0.166520 & -0.957046 & 0.3474 \\
\hline D(LNGDP(-1)) & -0.037457 & 0.211654 & -0.176973 & 0.8609 \\
\hline D(LNGDP(-2)) & 0.235324 & 0.178779 & 1.316285 & 0.1996 \\
\hline D(LNCPI(-1)) & 0.122199 & 0.191011 & 0.639749 & 0.5279 \\
\hline D(LNCPI(-2)) & -0.118109 & 0.168830 & -0.699576 & 0.4904 \\
\hline $\operatorname{ECM}(-1)$ & -0.415620 & 0.180405 & -2.303818 & 0.0295 \\
\hline R-squared & 0.313026 & \multicolumn{2}{|c|}{ Mean dependent var } & 0.023330 \\
\hline Adjusted R-squared & 0.154493 & \multicolumn{2}{|c|}{ S.D. dependent var } & 0.118461 \\
\hline S.E. of regression & 0.108927 & \multicolumn{2}{|c|}{ Akaike info criterion } & -1.410445 \\
\hline Sum squared reside & 0.308493 & \multicolumn{2}{|c|}{ Schwarz criterion } & -1.093004 \\
\hline Log likelihood & 30.27234 & \multicolumn{2}{|c|}{ F-statistic } & 1.974519 \\
\hline Durbin-Watson stat & 1.950221 & \multicolumn{2}{|c|}{ Prob(F-statistic) } & 0.106150 \\
\hline Log likelihood & 30.51542 & \multicolumn{2}{|c|}{ F-statistic } & 5.332259 \\
\hline Durbin-Watson stat & 2.108031 & \multicolumn{2}{|c|}{ Prob(F-statistic) } & 0.010031 \\
\hline
\end{tabular}


Table 16. Error Correction Mechanism - B

Dependent Variable: D(LNGDP)

Method: Least Squares

Sample(adjusted): 1971 -2010

Included observations: 39 after adjusting endpoints

\begin{tabular}{|c|c|c|c|c|}
\hline Variable & Coefficient & Std. Error & t-Statistic & Prob. \\
\hline $\mathrm{C}$ & 0.049168 & 0.030173 & 1.629534 & 0.1130 \\
\hline $\mathrm{D}(\mathrm{LNCPI})$ & -0.118243 & 0.130236 & -0.907910 & 0.3707 \\
\hline $\operatorname{ECM}(-1)$ & -0.436048 & 0.137288 & -3.176163 & 0.0033 \\
\hline R-squared & 0.249962 & \multicolumn{2}{|c|}{ Mean dependent var } & 0.029050 \\
\hline Adjusted R-squared & 0.203085 & \multicolumn{2}{|c|}{ S.D. dependent var } & 0.118541 \\
\hline S.E. of regression & 0.105821 & \multicolumn{2}{|c|}{ Akaike info criterion } & -1.572310 \\
\hline Sum squared resid & 0.358342 & \multicolumn{2}{|c|}{ Schwarz criterion } & -1.438994 \\
\hline Log likelihood & 30.51542 & \multicolumn{2}{|c|}{ F-statistic } & 5.332259 \\
\hline Durbin-Watson stat & 2.108031 & \multicolumn{2}{|c|}{ Prob(F-statistic) } & 0.010031 \\
\hline
\end{tabular}

Table 17. Error Correction Mechanism - C

Dependent Variable: LNGCF

Method: Least Squares

Sample: 1970- 2010

Included observations: 40

\begin{tabular}{ccccc}
\hline \hline Variable & Coefficient & Std. Error & t-Statistic & Prob. \\
\hline \hline C & 15.87351 & 1.225854 & 12.94894 & 0.0000 \\
LNINTR & 0.290494 & 0.618099 & 0.469979 & 0.6414 \\
\hline \hline R-squared & 0.006455 & Mean dependent var & 16.42260 \\
Adjusted R-squared & -0.022767 & S.D. dependent var & 2.201880 \\
S.E. of regression & 2.226804 & Akaike info criterion & 4.492965 \\
Sum squared resid & 168.5943 & Schwarz criterion & 4.580938 \\
Log likelihood & -78.87336 & F-statistic & 0.220881 \\
Durbin-Watson stat & 0.022763 & Prob(F-statistic) & 0.641370 \\
\hline \hline
\end{tabular}

Table 18. Error Correction Mechanism - D

Dependent Variable: D(LNGCF)

Method: Least Squares

Sample(adjusted): 1972- 2010

Included observations: 38 after adjusting endpoints

\begin{tabular}{ccccc}
\hline \hline Variable & Coefficient & Std. Error & t-Statistic & Prob. \\
\hline \hline C & 0.157905 & 0.060500 & 2.609992 & 0.0142 \\
D(LNGCF(-1)) & 0.161657 & 0.185141 & 0.873155 & 0.3898 \\
D(LNINTR) & 0.037037 & 0.279126 & 0.132690 & 0.8954 \\
D(LNINTR(-1)) & -0.311287 & 0.279664 & -1.113076 & 0.2748 \\
ECT(-1) & -0.017833 & 0.031422 & -0.567532 & 0.5747 \\
\hline \hline R-squared & 0.062974 & Mean dependent var & 0.186060 \\
Adjusted R-squared & -0.066271 & S.D. dependent var & 0.280199 \\
S.E. of regression & 0.289334 & Akaike info criterion & 0.492585 \\
Sum squared resid & 2.427717 & Schwarz criterion & 0.717050 \\
Log likelihood & -3.373952 & F-statistic & 0.487242 \\
Durbin-Watson stat & 1.879326 & Prob(F-statistic) & 0.744977 \\
\hline \hline
\end{tabular}




\section{REFERENCES}

[1] S. Ahmed, \& J. Rogers. Inflation and the great ratios: long term evidence. Journal of Monetary Economics. Vol. 45.No. $5,210-223$.

[2] CBN. Central Bank Monetary Policy Committee; CBN Communiqué No. 89 of the Monetary Policy Committee Meeting, held on Monday, May 20th and Tuesday, 21st, Abuja, Nigeria, 2013.

[3] J. Obadeyi. The impact of interest rates on the development of an emerging-market: empirical evidence of Nigeria. Journal of Economics and Sustainable Development. Vol. 10. No. 4, 44 -51.

[4] M. Abata; J. Kehinde, \&S. Bolarinwa. Fiscal / monetary policy and economic-growth in Nigeria: A theoretical exploration. Journal of Academic Research in Economics and Management Sciences. Vol. 1. No. 5, 1-13.

[5] J. Adam. Banking Sector Reforms: The Policy Challenges of Bank Consolidation in Nigeria. A paper presented at the 46th Nigerian Economic Society in Abuja.2005

[6] S.Kwan. Banking consolidation: federal resource bank of San Francisco (FABSF) Economic letter, June 18, 12 -14, 2004.

[7] M. Ahmad. Distress in banks: A general overview of the roles of directors. NDIC Quarterly Journal, Vol. 2. No. 1, 58 -78 .

[8] R. Baro, \&M. Sala. World Real Interest Rates. NBER Working Paper. No.3317, April.1990.

[9] T. Hajela. Money, Banking and Public Finance. Ane Books Press, New Delhi, 2009.

[10] M. Kent, \& T. John. The Economics of Banking. John Wiley \& Sons Press, Australia, 2008.

[11] L. Chiette. Macro-Economic Determinant of Private Savings in Nigeria. National Institute of Social and Economic Research" (NISER) Monograph Series 7.1992

[12] B. Adeoye. Economic Policy Shift, Agro Climatic Condition and Inflation in Nigeria, 1970-1999, NISER, Monograph Series No. 7.2002.

[13] B. Ebong. The Banking Industry and the Nigerian Economy: Post consolidation. Union Digest Vol. 9. No. 4, 21 -25.

[14] A. Soyibo, \& F. Adekanye. Financial System Regulation, Deregulation and Savings Mobilization in Nigeria. AERC Research Paper No 11, Nairobi; AERC, 1992.

[15] M. Bruno. Inflation, Growth and Monetary Control: Non Linear Lessons from Crisis and Recovery, Paolo Balfi Lecturers on Money and Finance, Rome: Banca d' Italia, 1995.

[16] G. Debele. Inflation Targeting and Output Stabilization. Reserve Bank of Australia, Research discussion paper, 53 $-62,1999$.

[17] G. Haynes. The Emerging Regulatory and Supervisory Framework for Managing Risk in the Caribbean Banking
Sector. Paper presented at the Seminar on Risk Management and Investment in the Caribbean, $22-43,2005$

[18] S. Aiyagari; R. Braun, \& Z.Eckstein. Transaction services, inflation and welfare. Journal of Political Economy. Vol. 5.No.16, $74-86$.

[19] M. Jhinghan. Macro-Economic Theory. Veranda Publication Ltd, New Delhi, 1994.

[20] M. Hall. Japan's big bang: The likely winners and losers.Journal of International Banking Law. Vol. 2. No. 4, 210-216.

[21] M. Reinhart, \&S. Rogoff. The aftermath of financial crisis. Journal of American Economic. Vol. 99, No. 105, 466 -470 .

[22] S. Andrianova; O. Demetiades, \& A. Shortland. State Banks, Institution and Financial Development. Discussion Paper in Economics, University of Leicester, 2 -13.2003.

[23] O. Nnanna. Beyond Bank Consolidation On The Impact Of Society. A paper presented at the 4th Annual Monetary policy conference of the CBN, Abuja, 18 -19, 2004.

[24] Schclarek, A. Debt and Economic Growth in Developing Industries, Mimeo Press, United States, 2004.

[25] O. Ekwu, \& E. Ugbwu. Consolidation: CBN Dilemma over Undercapitalized Banks. The Guardian, Wednesday, November 9, 27.2005.

[26] J.Akhavin, \&D. Berger. The effect of mega mergers on efficiency and prices; evidence from a bank profit function: A review of industrial organization. Journal of Management and Finance. Vol. 2. No.6. 112 -126.

[27] C. Beddies. Investment, Capital Accumulation and Growth: Some Evidence from Gambia: 1964-1998. || IMF Working Paper 99/117, August. , 1999.

[28] K. Adeyemi. Banking sector consolidation in Nigeria: issues and challenges. Union digest Vol. 9, No. 3, 50 -62.

[29] A. Khosravi, \& M. Karimi. To investigate the relationship between monetary policy, fiscal policy and economic growth in Iran: Autoregressive distributed lag approach to co-integration. American Journal of Applied Sciences, Vol. 7. No.3, $420-423$..

[30] National Bureau of Statistics (NBS). A meeting organized the Bureau in Lagos.

[31] United Nations Conference on Trade and Development. Development and Globalization: Facts and Figures. United Nations Publication, New York, 2008.

[32] K. Nwaigwe. Consolidated Supervision of Banks in Nigeria: Lessons from other countries, NDIC Quarterly Journal, Vol. 12. No. $16,70-85$.

[33] S. Akintola. Banks move against soludo. Nigerian tribune, Friday 23, 11.2004

[34] N. Chike. Bank recapitalization: the imperatives, implications, options and strategies for banks.Journal of Nigerian Banker, CIBN, Jan - March, Vol. 3. No. 9, 6-17.

[35] J. Sanusi. Deregulating the Nigerian economy: achievements and prospects: economic and financial review. The Central Bank of Nigeria, Vol. 26, No. 4, 32-40. 
[36] G. Caporale; A.Cipollin, \&P. Demetriades, (2005),"Monetary Policy and the Exchange Rate: During the Asian crisis," Journal of International Money and Finance, Vol. 24. No. 1, 35-53.

[37] J. Ebhiodagbem. Causes and environmental effects of banks failures in Nigeria. NDIC Quarterly Journal, Vol. 5. No. 3, $15-31$.

[38] M. Unegbu. Capacity building in the banking, The Guardian, Monday, November, 21, $56-57,2005$.

[39] R. Akingunola. Financial deregulation and efficiency in the Nigerian capital market. Journal of Accounting and Management Sciences. Vol. 1. No 1, 45.

[40] T.Lemo. Regulatory Oversight and Stakeholder Protection. A paper presented at the BGL Mergers and Acquisitions Interactive Seminar, Eko Hotels \& Suits, Victoria Island, Lagos, 2005.

[41] E. Shaw. The sequencing of economic reform: Analytical issues and lessons from latin America experience. Journal of World Economy. Vol. 13. No. 1, 1-13.

[42] C. Azariadis, \&A. Drazen. Threshold externalities in economic development. Quarterly Journal of Economics Vol. 1. No.5, 501-526.

[43] M. Adebiyi. Can high interest rate promote economic growth without fuelling inflation in Nigeria? Journal of Economics and Social Studies. Vol.10. No.6, 86-100.

[44] G. Agagi. Capital formation and the Nigerian economy. Journal of Economic and Financial Review. Vol.38. No.2, 28-32.

[45] R. Alan. High interest rate: A new conventional wisdom for development policy-conclusion from sri-lanka experience. Journal of World Development. Vol.10.No.3, 211-222.

[46] R. McKinnon. Money and Capital in Economic Development. Washington, Brookings Institution.

[47] C. Phillips, \& P. Perron. (Testing for a Unit Root in Time Series Regression, Bio-metrica, 75; 335 -346: Ricardo, D. (1870): Principles of Political Economy and Taxation, 1988.

[48] A. Koutsoyiannis. Theory of Econometric. Macmillan
Publisher, London, 1997.

[49] D. Gujarati. Basic Econometrics. Published by McGrawHill Press, New Delhi, 2003.

[50] S. Johansen. Statistical analysis of coin-integrated vectors. Journal of Economic Dynamic and Control, Vol.4. No.12, $231-240$.

[51] J. Sargan, \& A. Bhargara. Testing residuals from least squares regression for being generated by the Gaussian random walk. Econometrical, Vol.51. No.1, 153 - 159.

[52] World Economic Situation and Prospects. Global Economic Outlook. United Nations Publication, New York, 2013.

[53] World Economic and Social Survey. In Search of New Development Finance. United Nations Publication, New York, 2012.

[54] K. Gary. Introduction to Econometrics, John Wiley \& Sons Press, Chi-Chester- UK, 2008.

[55] S.Isiaka; A. Abdul-Raheem, \&I. Mustapha. Impact of fiscal and monetary policies on the level of economic activities in Nigeria. Laipa Journal of Management Science, Vol. 1. No.1, 5-7.

[56] F. Mwega \& S. Ngola. The role of interest rates in the mobilization of private savings in Africa-case study of Kenya. Journal of Economics and Finance. Vol.1. No. 1, 1-9.

[57] A. Marcus;A. Kane, \&Bodie, Z. Investment. McGraw- Hill, New Delhi, 2002.

[58] E. Shaw. Financial Deepening in Economic Development. Oxford University Press, New York, 1973.

[59] M. Nyoung. The dynamic savings in a deregulated economy-some theoretical and empirical extension. Quarterly NDIC Journal. Vol. 7. No. 3, 6.

[60] B. Bernanke, \& F. Mishkin. Inflation targeting: A new framework for monetary policy? Journal of Economics Perspectives, Vol. 11. No.2, 102 -128.

[61] A. Moses. Introduction to Capital Formation and Economic Growth. Published by Princeton University Press, New Jersey, 1955. 